\title{
Profit Analysis of Virus Free Sweet Potato and Vine Multiplication by Smallholder Farmers in Selected Regions of Tanzania
}

\author{
Castory Kibiki ${ }^{1,}$, , Khamadin Daud Mutabazi ${ }^{1}$, Fred Tairo ${ }^{2}$ \\ ${ }^{1}$ Department of Agricultural Economics, Sokoine University of Agriculture, Morogoro, Tanzania \\ ${ }^{2}$ Tanzania Agricultural Research Institute, Mikocheni, Dar es Salaam, Tanzania
}

Email address:

Kibikicastory268@gmail.com (C. Kibiki)

${ }^{*}$ Corresponding author

\section{To cite this article:}

Castory Kibiki, Khamadin Daud Mutabazi, Fred Tairo. Profit Analysis of Virus Free Sweet Potato and Vine Multiplication by Smallholder Farmers in Selected Regions of Tanzania. International Journal of Agricultural Economics. Vol. 9, No. 5, 2020, pp. 99-105.

doi: $10.11648 /$ j.ijae.20200504.12

Received: June 2, 2020; Accepted: June 23, 2020; Published: July 13, 2020

\begin{abstract}
Sweet potato production using certified virus free vines and virus free vine multiplication promote high yields which are significant for enhancing food security and income generation among small holder farmers. This study examines the cost and benefit of sweet potato tuber production using certified virus free vines and virus free vine multiplication among smallholder farmers in the Lake Victoria and Coastal Zones in Tanzania. Primary data were collected from 495 sweet potato farmers and virus free vine multipliers using survey tool (questionnaire). About 362 farmers who are producers sweet potato tubers and 133 farmers who are virus free vine producers were chosen from each zone using simple random sampling technique. The cost and benefit analysis were calculated using Microsoft Excel 2007. The findings of the study showed that the benefit of sweet potato production using certified virus free vines in Lake Victoria Zone was 1,284,665.64 Tanzanian shillings per hectare and that in Coastal Zone was 1,159,524.60 Tanzanian shillings per hectare. Furthermore, was revealed that benefit of virus free sweet potato vine multiplication in Lake Zone was 219,086.54 Tanzanian shillings per hectare and in Coastal Zone was 305948.59 Tanzanian shillings per hectare. The Benefit Cost Ratio obtained in sweet potato production using certified virus free vines in Lake Zone was 5.04 per hectare and Coastal zone was 3.71 per hectare. The Benefit Cost Ratio obtained in virus free sweet potato vine multiplication in Lake Zone was 2.91 per hectare and Coastal zone was 2.11 per hectare. Therefore, investment in sweet potato tuber production using virus free vines and virus free vine multiplication is worth undertaking in both Zones since farmers generate profit and hence enhanced food security.
\end{abstract}

Keywords: Cost-Benefit, Income Generation, Planting Materials, Viral Disease

\section{Introduction}

Sweet potato is one of the most important food crops worldwide. It is an important root crop in Tanzania after cassava and potato. Its ability to yield better even in marginal soils and conditions where other crops fail [1], make it appeals to low resource subsistent farmers particularly women. With its annual production of 4.2 MT per annual, Tanzania is the leading producer in Africa, and accounts for $3.8 \%$ of the world's sweet potato production [2].

Despite high annual production, average production is still far below the estimated sweet potato potential yield of $15-23 \mathrm{t}$ $\mathrm{ha}^{-1}$ [3]. The low productivity is contributed by numerous constraints both abiotic and biotic. The main biotic constraints are limited access to certified high-quality improved planting materials [4], which is partly exacerbated with prevalence of viral diseases $[5,6]$ and weevils infestations

Overreliance on tradition seed delivery system from farmer to farmer [7] and/or recycling of owns seed from previous crop [6], not only contribute to further spread and persistent of Sweet Potato Virus Disease (SPVD), but also dissemination of inferior cultivars.

Sweet potato unlike potato for many years suffered lack of 
official system for production and delivery of certified planting materials [8]. Several initiatives at some point each contributed specific interventions in developing and institutionalizing a sustainable seed delivery system in Tanzania, by strengthening and modernizing the existing traditional seed system [9-11]. However, the delivery of improved planting materials remained low, inconsistent and unsustainable.

The continuous efforts by sweet potato seed sector focuses on multiplication and delivery of improved varieties with emphasis on improved certified planting materials. The institutionalization of the sustainable system is enhanced by the enforcement of seed certification standards [12], which guides on the multiplication and certification procedures for all grades of sweet potato seeds prior to selling.

Since 2018 the ICOPSEA project granted by the Swedish International Development Aid (SIDA) to National Agricultural Research Systems (NARS) in East Africa through Bio innovate II program has been supporting the institutionalization of a sustainable system through technical and infrastructure supports to key actors in the seed delivery chain particularly vine multipliers and processors to increase sweet potato production and market.

However, farmers are reluctant to use certified seeds complaining that supply is limited and expensive. While vine multipliers also complained the demand for certified seed is low and production costs are high due to high certification standards required, that's makes the venture less profitable compared to traditional system.

Therefore, this study was carried out to determine the levels of profit efficiency in the production of sweet potato using certified virus free vines and/or multiplication improved certified virus free vines by smallholder farmers in selected regions of Tanzania. Also to determine the factors that can greatly aid producers and vine multipliers to make successful investment decisions, and policymakers in creating efficiency enhancing policies to support the system. Specifically, the study seeks to: (1) determine cost structure for production of sweet potato using certified seed and multiplication of certified vines (2) estimate and compare the benefit-cost ratio (BCR) of tubers and vine producers. Moreover, the existing constraints for further development of sustainable delivery system are discussed.

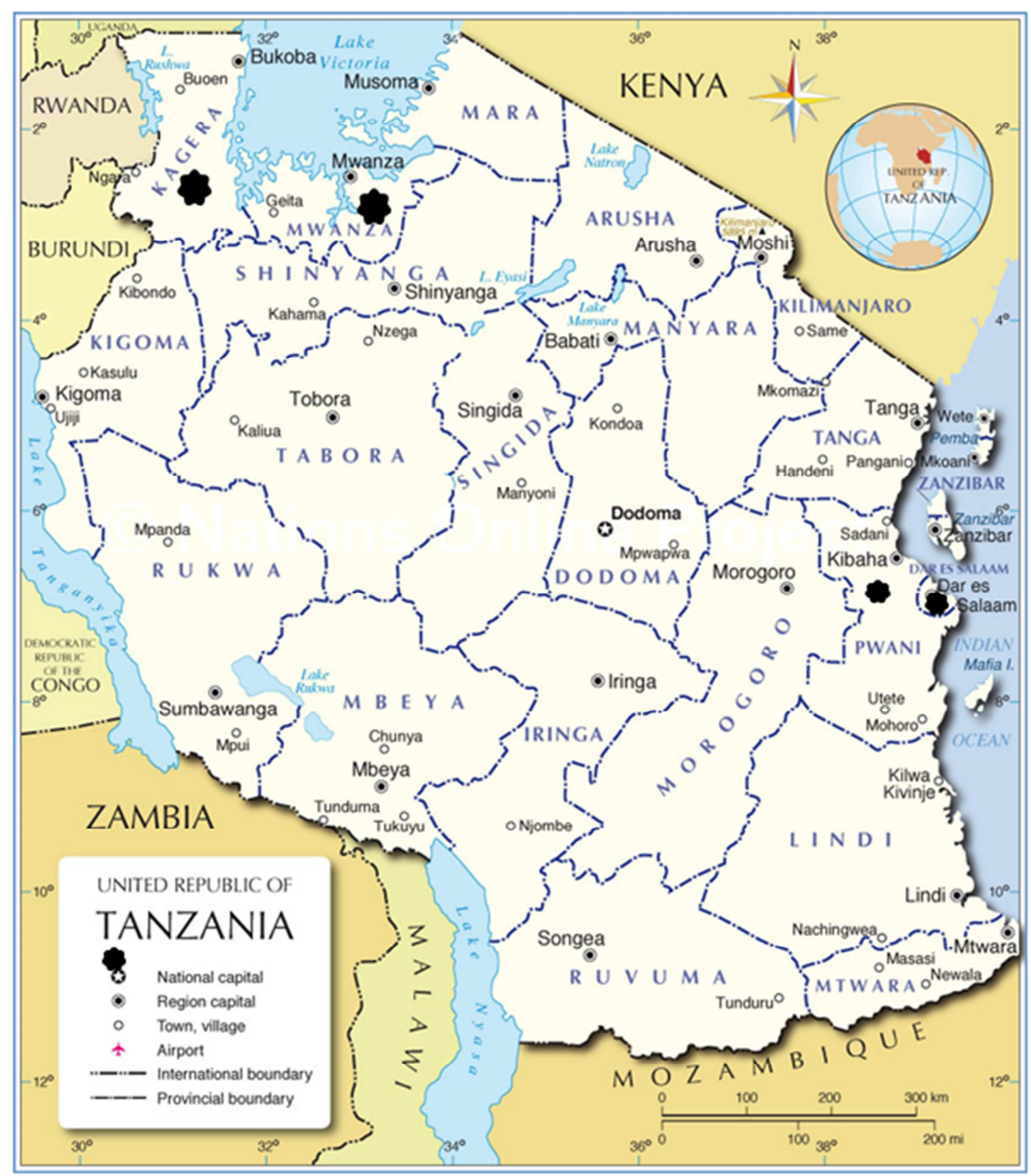

Figure 1. Map of Tanzania showing surveyed regions within agro-ecological zone (courtesy of https://www.nationsonline.org/oneworld/map/tanzaniaadministrative-map.htm). 


\section{Material and Methods}

\subsection{Description of the Study Areas}

This study was conducted in four selected sweet potato main growing regions (Kagera and Mwanza) in the Lake Victoria zone (LVZ) and (Dar es Salaam and Pwani) in the Coastal zones of Tanzania. The LVZ is located in North West of Tanzania in the Lake Victoria basin (Figure 1). It is characterized by humid and overcast during wet season, windy and partly cloudy during dry season, and temperature varies from $62^{\circ} \mathrm{F}$ and $83^{\circ} \mathrm{F}$ climate with annual rainfall of $1001 \mathrm{~mm}$ and population of nearly $10,180,348$ million. The zone is the main root crop producer with annual production of 71,007 tons per year.

The Coastal zone lays along the Indian Ocean on the eastern part (Figure 1). The zone is characterized by having a hot weather all year round, with two rainy seasons in the northern part, and only one in the southern part, with annual rainfall of $1,150 \mathrm{~mm}$ and population of 5,463,668 million. Its sandy loam soil type ideal for sweet potato production and being within the commercial city (Dar es Salaam) of Tanzania sweet potato is one of the important commercial crops within the zone.

The two agro-ecological zones were selected based on their experience in previous interventions supports to sweet potato seed system from various initiatives [9, 10, 13] to establish a formal seed delivery system.

\subsection{Sampling Techniques and Sample Size}

Multi-stage sampling is a further development of the principle of cluster sampling. In this study multistage sampling was applied in such a way that sampling frame was developed in partial units. Thus; the study applied multistage sampling where by sampling was divided into four stages namely; $1^{\text {st }}$ Agro-ecological zone, $2^{\text {nd }}$ Regions, $3^{\text {th }}$ District and $4^{\text {th }}$ Wards within regions. The first stage was to select primary sampling unit which was growing zones namely: Lake Zone and Coastal Zone, then followed by selecting regions namely Mwanza and Kagera in Lake Zone, Dar es Salaam and Pwani in Coastal Zone, followed by the selection of District and finally Wards.

Also, simple random sampling techniques were used in this study, whereby all sweet potato producers and vine multipliers were listed and randomly selected per each zone. The sampling frame from the study area was 3,956 sweet potato actors and sample size constituted a total of 364 sweet potato producers from selected Regions. For the case of sweet potatoes vine multipliers each saves 20 farmers, so for 3,956 farmers were; $3959 / 20=198$ vine multipliers

Sweet potato producers were 3,956-198 $=3,758$

The sample size was calculated according to the formula described by Kothari [14] as follows;

$$
n=\frac{N}{1+N(e)^{2}}
$$

Where: $\mathrm{n}=$ sample size, $\mathrm{N}=$ sampling frame, $\mathrm{e}=$ level of precision (sampling error 5\%)

Sample size for vine producers sample size for sweet potato producers

$$
\begin{aligned}
& n=\frac{198}{1+198(0.05)^{2}}, n=133 \\
& n=\frac{3758}{1+3758(0.05)^{2}}, n=362
\end{aligned}
$$

Total respondents were 495

Respondent's breakdown in the study areas according to zone is highlighted in (Table 1)

Table 1. Respondent's breakdown in the study areas.

\begin{tabular}{llll}
\hline Regions & Stratum & $\begin{array}{l}\text { Sampling } \\
\text { Fraction } \mathbf{n} / \mathbf{N}\end{array}$ & $\begin{array}{l}\mathbf{n} / \mathbf{N}_{\mathbf{X}} \text { Sub- } \\
\text { population }\end{array}$ \\
\hline Kagera & 1500 & 0.125 & 188 \\
Mwanza & 1256 & 0.125 & 157 \\
Dar es salaam & 275 & 0.125 & 34 \\
Pwani & 925 & 0.125 & 116 \\
Total & 3956 & & 495 \\
\hline
\end{tabular}

\subsection{Data Collection}

In order to access real data, data collection exercise was done between February and March 2019 in both zones when the crop was in the field. The data collected comprised primary data and secondary data. Collection of primary data was achieved using structured questionnaires, from key actors in the sweet potato value chain: mainly farmers, decentralized vine multipliers (DVM), District Agricultural, Irrigation and Cooperatives Officer (DAICO), Village extension officers, and Sweet potato processors.

\subsection{Data Processing and Analysis}

Analytical framework on net present value and benefit: cost ratio

The viability of an investment can be evaluated using several financial ratios including break-even analysis, payback period analysis, benefit-cost ratio (BCR), net present value (NPV), internal rate of return (IRR) and its modifications etc. All of these methods have their strengths and weaknesses. The BCR, NPV and IRR analyses have been chosen for the present study due their simplicity and wide appeal among both financial experts and the uninitiated. The quantitative analysis which involved benefit-cost analysis was calculated using Microsoft Excel 2007.

\subsection{Analysis of Cost and Benefit for Sweet Potato Tuber Production/Vines Multiplication}

Cost and benefit of vine multiplication were analyzed by considering variables which are quantity of inputs and outputs, price, and cost of production which included rent, labor and transport.

Cost function

Total cost (TC) was obtained through the following formula; Total cost (C) is total variable cost (TVC) plus total fixed 
$\operatorname{cost}(\mathrm{TFC})$

$$
\mathrm{TC}=\mathrm{TVC}+\mathrm{TFC}
$$

Where by

$$
\text { TVC = PY (Price X Quantity of variable inputs) }
$$

Benefit function

Then; benefit was calculated using total revenue (TR) formula

$$
\mathrm{TR}=\text { Price } \mathrm{x} \text { Quantity of output }=\text { PQ }
$$

Thus, Net benefit will be obtained using the formula below

$$
\text { Net benefit }=\mathrm{TR}-\mathrm{TC}
$$

\subsection{Costs-Benefit Analysis}

As indicated earlier, Net Present Value (NPV), BenefitCost Ratio (B/C) and Internal Rate of Return (IRR) are used in analyzing the economic viability of development projects. In this study, NPV, B/C ratio and IRR was used with the following formulae:

Net Present Value (NPV)

$$
N P V=\sum_{t=1}^{n} \frac{B_{t}-C_{t}}{(1+i)^{t}}
$$

Benefit-Cost Ratio (B/C)

$$
\frac{B}{C}=\frac{\sum_{t=1}^{n} \frac{B_{t}}{(1+i)^{t}}}{\sum_{t=1}^{n} \frac{C_{t}}{(1+i)^{t}}}
$$

Internal Rate of Return (IRR)

$$
\text { IRR where } N P V=\sum_{t=1}^{n} \frac{B_{t}-C_{t}}{(1+i)^{t}}=0
$$

OR

$$
I R R-L D R+(U D R-L D R T)\left[\frac{N P V_{1}}{N P V_{1}-N P V_{2}}\right]
$$

Where

$B_{t}=$ benefit in year $\mathrm{t}$;

$C t=$ cost in year $\mathrm{t}$;

$t=1,2,3 \ldots$

$n=$ number of years;

$i=$ interest (discount) rate

$L D R=$ lower discount rate at which NPV is positive;

$U D R=$ upper discount rate at which NPV is negative;

$N P V_{1}=$ Net Present Value at the lower discount rate; and

$\mathrm{NPV}_{2}=$ Net Present Value at the upper discount rate

The $\mathrm{B} / \mathrm{C}$ ratio indicator is equivalent to the ratio of the present value of benefits to the present value of costs. If there is no limitation of funds, the decision criterion is to accept having $\mathrm{B} / \mathrm{C}$ ratio greater than 1 .

\subsection{Choosing the Discount Rate}

In economic analysis the discount rate is the interest rate or the opportunity cost of invested capital. Usually, it is difficult to estimate an exact discount rate, however, the World Bank proposed $10 \%$ to $12 \%$ as an opportunity cost of capital for Tanzania. Therefore, the discounting rate adopted in the present study was $12 \%$. However, since many farmers in the study areas are members of the Savings and Credit Cooperative Society (SACCOS), a lending discount rate of $18 \%$ was also used as an opportunity cost of capital for the present study which was used to determine what might happen to NPVs.

\section{Results and Discussion}

In this section the cost used and benefit obtained from virus free sweet potato (VFSP) and vine multiplication are presented and discussed. This was achieved by analyzing the total cost (TC), average cost (AC), total benefit and net benefit of VFSP and the extent to which cost and benefits differ between zones.

\subsection{Cost and Benefit Tanzanian Shillings per Hectare (TZS/ha) Associated with certified Virus Free Vine Multiplication}

The study findings showed that overall in the Lake Victoria Zone cost of vine multiplication was $114,850.43$ $\mathrm{TZS} /$ ha, benefit was $333,936.97 \mathrm{TZS} / \mathrm{ha}$ with the net benefit of 219,086.54 TZS/ha, while in Coastal zone cost of vine multiplication was $145,042.84 \mathrm{TZS} / \mathrm{ha}$, with benefit of $305,948.59 \mathrm{TZS} / \mathrm{ha}$ and net benefit was $160,905.75 \mathrm{TZS} / \mathrm{ha}$ (Table 2). The findings demonstrate that, vine multiplication is a profitable venture to producers and multipliers since it provided a positive benefit in both zones.

Certified Vines are sold per cutting whereby Cost of certified vine is $60-70 \mathrm{TZS} /$ vine cutting. One hector requires $10,000 \mathrm{sqm} / 0.3 \mathrm{sqm}=33,333$ vines.

However, vine cuttings are mostly sold in bundles of different sizes (small and big bundles) in which a big bundle consists of 20 small bundles, each containing 50 vines. This is because the introduction of VF variety came when farmers were used to planting local variety as traditionally adopted, this led the VF vine multipliers to use the bundle techniques as traditionally accepted in order to attract farmers to accept the directed price. This factor also led vine multipliers to be flexible and allow farmers to buy whatever quantities they desire, packaged either in small or in big bundles whereby prices depend on the bundle size and the buyer's situation.

Table 2. Cost and benefit vine multiplication.

\begin{tabular}{lll}
\hline Category & Lake Zone & Coastal Zone \\
\hline Description per ha & & \\
\hline Cost & 114850.43 & 145042.84 \\
Benefit & 333936.97 & 305948.59 \\
Net benefit & 219086.54 & 160905.75 \\
\hline
\end{tabular}

\subsection{Average Cost and Benefit (TZS/ha) Associated in certified VFSP Vine Multiplication}

The results revealed that the average cost in vine multiplication in Lake Zone is $116,847.83 \mathrm{TZS} / \mathrm{ha}$, minimum cost of production is $50,000 \mathrm{TZS} / \mathrm{ha}$ and maximum cost of 
production is $250,000 \mathrm{TZS} /$ ha while average benefit and net benefit is $339,744.57 \mathrm{TZS} / \mathrm{ha}$ and $222,896.74 \mathrm{TZS} / \mathrm{ha}$ respectively (Table 3 ). Also, in average, minimum and maximum cost of vine multiplication in Coastal Zone was $150,000 \mathrm{TZS} / \mathrm{ha}, 30,000 \mathrm{TZS} / \mathrm{ha}$ and 280,000 TZS/ha respectively while the average benefit was $312,450 \mathrm{TZS} /$ ha and net benefit was $164,325 \mathrm{TZS} / \mathrm{ha}$. This outcome is attributed by reason that in Lake Zone the demand of vine is high since there is a relative high production per unit area; also, the number of farmers engaged in sweet potato production is relatively high compared to Coastal Zone.

Table 3. Average cost and benefit in vine multiplication.

\begin{tabular}{llll}
\hline Category & Cost & Benefit & Net Benefit \\
\hline Lake Zone & & & \\
\hline Average & 116847.83 & 339744.57 & 222896.74 \\
Minimum & 50000.00 & 67500.00 & 7500.00 \\
Maximum & 250000.00 & 600000.00 & 450000.00 \\
Coastal Zone & & & \\
Average & 150000.00 & 312450.00 & 164325.00 \\
Minimum & 30000.00 & $40,000.00$ & 36000.00 \\
Maximum & 280000.00 & 1000000.00 & 880000.00 \\
\hline
\end{tabular}

\subsection{Average Cost and Benefit of Certified VFSP Vine Multiplication Between Regions}

The table 4 present the average cost used in VFSP vine multiplication regional wise. Average cost is higher in Pwani region followed by Dar es Salaam and Kagera region while the lowest cost is in Mwanza. Furthermore, the benefit obtained per ha is worth in both regions, however the more benefit per ha is in Pwani and Dar es Salaam regions. The reason of this difference is that in Pwani and Dar es Salaam are within the commercial city (Dar es Salaam) so sweet potato is one of the important commercial crops in this zone. Not only that but also virus free sweet potato variety is not distributed in large area and is not adopted by big number of farmers compared to Mwanza and Kagera where the project started.

Table 4. Average cost and benefit in VFSP vine multiplication (TZS/ha).

\begin{tabular}{lllll}
\hline Category & Pwani & Dar-es-Salaam & Mwanza & Kagera \\
\hline Benefit & & & & \\
\hline Average & $330,133.33$ & $241,954.55$ & $336,454.55$ & $348,617.02$ \\
Maximum & $1,000,000.00$ & $600,000.00$ & $600,000.00$ & $600,000.00$ \\
Cost & & & & \\
Average & $150,166.67$ & $134,545.45$ & $104,090.91$ & $130,000.00$ \\
Maximum & $280,000.00$ & $270,000.00$ & $160,000.00$ & $250,000.00$ \\
\hline
\end{tabular}

\subsection{Cost and Benefit (TZS/ha) Associated with Tuber Production Using Certified VF Vines}

The study findings revealed that in the Lake Victoria zone cost of production was 254,948.12 TZS, benefit was $1,284,665.64 \mathrm{TZS} / \mathrm{ha}$ with net benefit of $1,029,717.52$ $\mathrm{TZS} /$ ha, while in Coastal zone cost of production was $312,482.67 \mathrm{TZS} / \mathrm{ha}$, with revenue of $1,159,524.60 \mathrm{TZS}$ and net benefit was $847,041.93 \mathrm{TZS} /$ ha (Table 5). The results demonstrated that, using certified planting materials benefitted sweet potato farmers. This was evident by the positive net benefit in both zones, which indicates that adopting certified virus free planting materials is profitable option compared to local materials.

However, in contrast the cost of production was high in coastal zone due to the awareness about market potentials of virus free sweet potato compared to Lake Zone.

Our findings agree with Fuglie et al [15] who recorded net benefit using virus free planting materials in Shandong province in China.

Table 5. Cost and benefit in sweet potato tuber production using certified VF vines.

\begin{tabular}{lll}
\hline Category & Lake Zone & Coastal Zone \\
\hline Description per ha & & \\
\hline Cost & $254,948.12$ & $312,482.67$ \\
Revenue & $1,284,665.64$ & $1,159,524.60$ \\
Net benefit & $1,029,717.52$ & $847,041.93$ \\
\hline
\end{tabular}

\subsection{Average Cost and Benefit Associated in Sweet potato Tubers Production Using Certified VF Vines}

The results displayed that the multiplication costs of certified planting materials in Lake Victoria zone ranged from $64,000 \mathrm{TZS} /$ ha to $986,000 \mathrm{TZS} /$ ha with an average cost of $312,912.74 \mathrm{TZS} / \mathrm{ha}$. The average revenue and net benefit were $1,576,745.28 \mathrm{TZS} / \mathrm{ha}$ and $1,263,832.55 \mathrm{TZS} / \mathrm{ha}$, respectively (Table 6). The multiplication cost in Coastal zone was slightly higher than LVZ, ranging from 64,000 $\mathrm{TZS} /$ ha to $1,011,000 \mathrm{TZS} / \mathrm{ha}$ with an average cost of $315,503.33 \mathrm{TZS} / \mathrm{ha}$. Similarly, the average revenue of $1,000,000.00 \mathrm{TZS} / \mathrm{ha}$ and net benefit of 595,000 TZS/ha accrued in Coastal zone was significantly lower (P-value 0.000116) than of LVZ. The positive net benefit of multiplication and selling of certified virus free SP vines in both agro-ecological zones indicates the business is beneficial to the small holder farmers per ha.

Table 6. Average cost and benefit in SP production.

\begin{tabular}{llll}
\hline Category & Cost & Benefit & Net benefit \\
\hline Lake Zone & & & \\
\hline Mean & $312,912.74$ & $1,576,745.28$ & $1,263,832.55$ \\
Minimum & $64,000.00$ & $250,000.00$ & $68,000.00$ \\
Maximum & $986,000.00$ & $8,000,000.00$ & $7,634,000.00$ \\
Coastal Zone & & & \\
Mean & $315,503.33$ & $1,000,000.00$ & $595,000.00$ \\
Minimum & $64,000.00$ & $250,000.00$ & $68,000.00$ \\
Maximum & $1,011,000.00$ & $5,000,000.00$ & $4,144,000.00$ \\
\hline
\end{tabular}

\subsection{Average Cost and Benefit in Sweet potato Tubers} Production Using Certified VF Vines between Regions $\mathrm{Ha}^{-1}$

The study stated that average cost used in production of VFSP tubers per ha in both regions is almost the same. However maximum cost used in production is higher in Dar es Salaam followed by Kagera while the lowest cost of production is in Pwani region followed by Mwanza (Table 7). Furthermore, the benefit obtained per ha is worth in both regions, however the more benefit per ha is in Mwanza and Kagera regions. The reason for this difference is that in Mwanza and Kagera region the area cultivated is higher 
which yield greater quantity of produce, and new variety was introduce first in these regions since sweet potatoes is among of the staple food in these regions. This implies that the proper strategy used to introduce virus free planting materials must be in place to other regions so that farmers can secure them easily.

Table 7. Average cost and benefit in VFSP production between regions (TZS/ha).

\begin{tabular}{lcccc}
\hline Category & Pwani & Dar-es-Salaam & Mwanza & Kagera \\
\hline Cost & & & & \\
\hline Average & $306,732.56$ & $319,843.75$ & $311,063.60$ & $319,902.17$ \\
Maximum & $504,000.00$ & $1,011,000.00$ & $856,000.00$ & $986,000.00$ \\
Benefit & & & & \\
Average & $886,686.05$ & $931,729.17$ & $931,780.03$ & $996,134.23$ \\
Maximum & $1,720,000.00$ & $1,550,666.67$ & $2,952,888.89$ & $2,895,111.11$ \\
\hline
\end{tabular}

\subsection{Costs-Benefit Analysis of Production Sweet Potato Tubers Using Certified VF Vines}

The analysis showed that, after discounting all benefits and costs at $12 \%$, all agro-ecological zones earned positive Net Present Value (Table 8). At $12 \%$ discount rate, LVZ generated 9,157,194.06 while in coastal zone a total; of 8 , $344,943.55$ were generated. In contrast, using $18 \%$ discount rate though NPV was still positive in both agro-ecological zones, the revenue generated from the investment in both zones was lower $(6,590,187.71$ in LVZ) and 5,693,821.23 in Coastal zone) than when $12 \%$ discount rate is used (Table 6). The positive indication of both analyzed discount rate in both agro-ecological zones indicates that costs can be recovered from the investment into the production of certified seeds.

Cost Benefit ratio was above one for both zones which ensure that investing in the two zones costs will be recovered at the end season (Table 8). Furthermore, the rate of return was below the opportunity cost of capital estimated which was $12 \%$. The cost benefit analysis indicates that production of sweet potatoes using virus free in both zones are worth undertaking.

The study matches with KARI [16] on their project analysis based on "Cost benefit analysis of sweet potato based on farm enterprises in central Uganda" their results of the CBA show that sweet potato production is a financially viable with regard to commercial production of tubers, vines, storage technologies and snack production. Also pointed out that is viable activity since technologies require low startup capital and the products are highly demanded.

Table 8. Results of Benefit Costs analysis in Tshs $h a^{-1}$.

\begin{tabular}{lllll}
\hline Category & Lake Zone & \multicolumn{3}{c}{ Coastal Zone } \\
\hline Rate & $12 \%$ & $18 \%$ & $12 \%$ & $18 \%$ \\
NPV & 9157194.06 & 6590187.71 & 8344943.55 & 5693821.23 \\
BCR & 5.04 & 4.21 & 3.71 & 2.80 \\
IRR & 0.0112 & 0.00039 & 0.0102 & 0.00034 \\
\hline
\end{tabular}

\subsection{Results of Costs-Benefit Analysis of Certified Virus Free Sweet Potato Vine Multiplication}

In case of certified virus free sweet potatoes vine multiplications, results revealed that, of the two discounting rates analyzed, all benefits and costs at both agro-ecological zones earned positive Net Present Values, with $12 \%$ earned slightly more than $18 \%$ (Table 9), which means that costs incurred in the multiplication of certified vines can be recovered.

Similar trend was observed for Cost-Benefit ratio which was above one in both agro-ecological zones, which ensures that investing in vine multiplications costs, will be recovered at the end of the season. The rate of return is below the opportunity cost of capital estimated which was $12 \%$. The cost benefit analysis indicates that production of sweet potatoes vine using virus free in both zones are worth undertaking.

The findings in the present study are supported by Fuglie et al [15] on their study on "Economic Impact of Virus-Free Sweet potato Planting Material" their result was that, the internal rate of return estimated to be 202 percent, with a net present value of $\$ 550$ million at 10 percent discount rate.

Table 9. Results of Benefit Costs analysis in Tshs ha-l.

\begin{tabular}{lllll}
\hline Category & Lake Zone & \multicolumn{3}{c}{ Coastal Zone } \\
\hline Rate & $12 \%$ & $18 \%$ & $12 \%$ & $18 \%$ \\
NPV & 3433615.20 & 1014938.33 & 2034899.95 & 1533633.88 \\
BCR & 2.91 & 1.9 & 2.11 & 1.1 \\
IRR & 0.0042 & 0.0005 & 0.0025 & 0.0009 \\
\hline
\end{tabular}

\section{Conclusion}

The measures used to evaluate virus free sweet potatoes and vine multiplication were NPV, CBR and IRR. The NPV was positive in both Zones; CBR was greater than one in both zones meaning that investing in VFSP and vine multiplication is worth undertaken in both Zones.

It was also established that actors in the SP tuber production using certified VF vines and VF vine multiplication performed differently in terms of economic benefits according to each zone. Generally, production of both vines and sweet potato tubers using virus free was found to have economic benefit in the study areas since the level of cost used was smaller compared to the benefit obtained. However, the extent of economic benefit varied between zones. The cost and benefit show that actors in Lake Zone obtained relatively higher benefit than actors in Coastal Zone.

The observed difference in economic benefit among actors in production of SP tubers and VF vines production was mainly attributed to difference in production level, cost used and area cultivated. Therefore, the findings of this study revealed that cost incurred in production and benefits achieved to the farmers were significant.

However, the study also found out that despite the positive return to investment incurred in multiplication and selling of certified VFSP planting materials, the business is very much challenged with the continuation of cheaply available inferior planting materials sold in bundles through traditional system. It is important for the government discourage selling of inferior materials through traditional system by enforcing the use of certified planting materials, which is one of the drivers 
of the sustainable seed system.

\section{Acknowledgements}

This work was supported by the Tanzania Agricultural Research Institute-Mikocheni (TARI-Mikocheni) through funds obtained from the Bio innovate Africa Programme Phase II under the ICOPSEA Project Grant no: BA/C1/2017-03. We are grateful to Ms. Magreth Lupembe of TARI Mikocheni Tanzania for her support during data collection.

\section{References}

[1] Kreuze, J. F, Perez, A, Gargurevich, M. G and Cuellar, W. J. (2020). Badnaviruses of Sweet Potato: Symptomless Coinhabitants on a Global Scale. Frontier in Plant Science, 11: 313. doi: $10.3389 /$ fpls.2020.00313.

[2] FAOSTAT (Food and Agriculture Organization Statistics). (2017) of the United Nations.

[3] Sebastiani S. K, Mgonja, A, Urio, F and Ndondi, T. (2007). Agronomic and economic benefits of sweet potato (Ipomoea batatas) response to application of nitrogen and phosphorus fertilizer in the northern highlands of Tanzania. The Eighth African Crop Science Society Conference, African Crop Science Society, El-minia, Egypt 2007, pp. 1207-1210.

[4] Ngailo, S, Shimelis, H. A, Sibiya, J and Mtunda, K. 2015. Sweet potato farming systems, production constraints and breeding priorities, Sugarcane Research Institute, Kibaha, Tanzania, Journal of Plant and Soil, pp 1-8.

[5] Tairo, F, Kullaya, A and Valkonen, J. P. T. 2004. Incidence of viruses infecting sweet potato in Tanzania. Plant Disease, 88 (9): 916-920.

[6] Ndunguru, G, Tomlins, K, Kimenya, F, Ngendello, T, Rwiza, E, Amour, R, Oirschot van, Q and Westby, A. 2008. On farm evaluation of methods for storing fresh sweet potato roots in East Africa, 47: 197-210.
[7] Karyeija, R, Kreuze, J, Gibson, R and Valkonen, J. 2000. Two Serotypes of Sweetpotato feathery mottle virus in Uganda and their Interaction with Resistant Sweetpotato Cultivars, Phytopathology, 90: 1250-5.

[8] Bio-Earn report. 2008. Bio-resources Innovations Network for Eastern Africa Development (Bio-Innovate).

[9] McEwan, M. 2016. Sweet potato Seed Systems in subSaharan Africa: A literature review to contribute to the preparation of conceptual frameworks to guide practical interventions for root, tuber and banana seed systems. Lima (Peru). 45 p. RTB Working Paper. ISSN 2309-6586. no. 20164.

[10] Mulongo, G, Maru, J, Munyua, H, Kasuga, R, Olapeju, P, Wende, M, Rubyogo, J. C and Gethi, J. 2018. The Building Nutritious Food Baskets Project 'Insights from the Field'. International Potato Center (CIP), Lima, Peru. 48 p. https://hdl.handle.net/10568/98539

[11] Mwiti, K. F. 2015. Assessment of willingness to pay for quality sweet potato planting materials, University of Nairobi, Kenya.

https://ageconsearch.umn.edu/record/269713/files/FLORINThesis.pdf

[12] Vernooy, R. 2017. Options for national governments to support smallholder farmer seed systems: The cases of Kenya, Tanzania, and Uganda. The Hague (Netherlands): Hivos, 26 p.

[13] URT (United Republic of Tanzania). 2017. Annual agriculture sample survey initial report 2016/17. https://nbs.go.tz/nbs/takwimu/Agriculture/2016_17_AAS_rep ort.pdf

[14] Kothari, R. C. 2004. Research Methodology, Methods and techniques, University of Rajasthan, India, New Age International publisher, 2nd Edition.

[15] Fuglie, O. K, Zhang, L, Salazar, F. L, Walker, S. T. 1999. Economic Impact of Virus-Free Sweet potato Planting Material in Shandong Province, China, International Potato Center Lima, Peru. 27p.

[16] KARI (Kawanda Agricultural Research Institute). 2019. Cost benefit analysis of sweet potato based on farm enterprises in central Uganda. 